\title{
Molecular Detection of Virulence Associated Genes in Salmonella Serovars Isolated from Raw Pork of Aizawl and Imphal
}

\author{
M. Das ${ }^{1}$, E. Motina ${ }^{1}$, D. Deka ${ }^{1}$, T.K. Dutta ${ }^{2}$, P. Roychowdhury ${ }^{2}$, \\ A. De ${ }^{3}$ and S. Chakraborty ${ }^{2 *}$ \\ ${ }^{I}$ Department of Veterinary Public Health \& Epidemiology, College of Veterinary Sciences \\ and animal Husbandry, Central agricultural University, Selesih, Aizawl, \\ Mizoram - 796014, India \\ ${ }^{2}$ Department of Veterinary Microbiology, College of Veterinary Sciences and animal \\ Husbandry, Central agricultural University, Selesih, Aizawl, Mizoram - 796014, India \\ ${ }^{3}$ Department of Veterinary Physiology and Biochemistry, CVSc \& AH, R.K. Nagar, West \\ Tripura - 799008, India \\ *Corresponding author
}

\section{A B S T R A C T}

\section{Keywords}

Salmonella, Virulence, PCR, Pork, Imphal, Aizawl

Article Info

Accepted: 04 June 2019 Available Online: 10 July 2019
The study was aimed to detect virulence associated genes of Salmonella serovars, which were isolated from raw pork samples of unorganised butcher shops of Aizawl and Imphal. A total of 5 Salmonella isolates (Aizawl=2, Imphal=3), belonging to Salmonella vircho $(\mathrm{n}=4)$, and Salmonella typhimurium $(\mathrm{n}=1)$, were obtained from 200 samples $(100=$ Aizawl and $100=$ Imphal) and screened for five virulence associated genes, namely invA, stn, pef A, sefC, $s p v \mathrm{C}$ by Polymerase Chain Reaction (PCR) technique. All Salmonella serovars detected positive for invA and stn genes, $s p v \mathrm{C}$ and pefA gene was found positive in Salmonella typhimurium and one Salmonella Vircho of Aizawl origin (overall $40 \%$ ). sefA was absent in all isolates. All the Salmonella serovars possessed invasive gene (invA) and enterotoxin gene $(s t n)$, which make them capable for producing gastroenteritis in human. Presence of Salmonella typhimurium positive with 4 virulence associated genes in Aizawl is a matter of worry from hygienic point of view.

\section{Introduction}

Food is one of the most essential needs for the survival of the living organisms and often acts as a major route for contaminants for the entry to the body (Das et al., 2018). Meat is considered as one of the most important food item for human consumption from the ancient time. A major proportion of the worldwide population chiefly relies on meat as a potent source of good quality protein (Bradeeba and Siyakumaar, 2013). If raw meat is not cooked properly with an adequate time and temperature conditions, it may cause serious harm to consumer's health. Visual detection of microbial contamination in raw meat and meat 
products not possible (Movassagh et al., 2010). The microbial population, that comes in contact with meat during the production, processing, transportation and distribution, acts as potential challenge to meat industry, and potentially creates hazards in form of infection, spoilage and intoxications (Dhanze et al., 2012). Out of different deadly foodborne infections, Salmonellosis is associated with hyperendemic diarrhoeal disease around the world affecting both human and animal alike (Prakash et al., 2005). Among six subspecies, Salmonella enterica causes $99.5 \%$ of food-borne illness in humans and animals (Pignato et al., 1998). The incidence of zoonotic transmission of nontyphoidal Salmonella serovars are largely associated with food of animal origin such as eggs, milk, poultry, beef and pork meat (Alcaine et al., 2007; Fernandez et al., 2012). The virulence of Salmonella is linked to a combination of chromosomal and plasmid factors. Virulence genes encode products that assist the organisms in expressing its virulence in the host cells. The chromosomally located invasion gene invA being thought to trigger the invasion of Salmonellae into cultured epithelial cells (Galan and Curtiss, 1989). Some genes are also known to be involved in adhesion and invasion, viz., sef (Clothier et al., 1993), pef (Baumler et al., 1996), inv (Galan et al., 1992); whereas some others are associated with survival in the host systemmgtC (Blanc-potard and Groisman, 1997) or in the actual manifestation of pathogenic processes, viz., sop (Wallis and Galyor, 2000), stn (Chopra et al., 1994). As pork is the major preferred meat and consumption of it is very high in North-eastern states of India, there are potential chances of transmission of Salmonella infection through meat to the people of this part of the country. Thus, the present study has been carried out to detect the presence of virulence associated genes in Salmonella serovars isolated from raw pork collected from Aizawl and Imphal cities.

\section{Materials and Methods}

A total of 5 Salmonella isolates were isolated from 200 raw pork samples, collected from different local unorganized butcher shops of Aizawl $(n=100)$ and Imphal $(n=100)$ cities. For serotyping, isolates were sent to National Salmonella and Escherichia Centre, Central Research Institute, Kasauli, Himachal Pradesh, India, and identified as Salmonella enteric serovar Vircho $(\mathrm{n}=4)$, and Salmonella enterica serovar Typhimurium $(\mathrm{n}=1)$. Those isolates were subjected for detection of virulence associated genes under this study. The selected virulence associated genes were invA (responsible for invasiveness), pefA (plasmid encoded fimbrial), sefC (Salmonella enteritidis fimbrial), $s p v \mathrm{C}$ (Salmonella plasmid virulence) and stn (Salmonella enterotoxin). Oligonucleotide primers (Eurofins Genomics India Pvt. Ltd., Bangalore, India), used for detection of the targeted genes are given in Table 1 (references). For positive control of all the mentioned genes in this study, standard culture of Salmonella enteritidis (ATCC 13076) was used.

The template DNA for PCR detection of virulence associated genes was prepared as per standard methods of Das et al., (2018). Salmonella isolates was grown in $5 \mathrm{ml}$ Luria Bertani (LB) broth and incubated at $37^{\circ} \mathrm{C}$ overnight under constant shaking. After incubation, $1 \mathrm{ml}$ of the bacterial broth culture was taken in a sterile microcentrifuge tube and centrifuged at $8000 \mathrm{rpm}$ at $4^{\circ} \mathrm{C}$ for 10 mins. The bacterial pellet thus obtained was washed thrice with sterile Normal Saline Solution $(\mathrm{NSS}, 0.85 \% \mathrm{w} / \mathrm{v})$ by centrifuging at 8000 rpm at $4{ }^{\circ} \mathrm{C}$ for 5 mins and finally pellet was re-suspended in $100 \mu 1$ of nuclease free sterile distilled water. The bacterial suspension was boiled for 15 mins in a boiling water bath followed by immediate chilling for $15 \mathrm{mins}$ at $-20^{\circ} \mathrm{C}$ (Snap chilling). The lysate was 
centrifuged again at $5000 \mathrm{rpm}$ for 5 mins to sediment the cell debris and the supernatant was used as template DNA for PCR assay.

The PCR reactions for identification of virulent genes were carried out following the protocol mentioned by Rahn et al., (1992), Murugkar et al., (2003) and Chiu et al., (2006), with slight modifications. Briefly, 25 $\mu \mathrm{l}$ of PCR mixture contained $12.5 \mu \mathrm{L}$ of $2 \mathrm{X}$ Dream taq PCR Master Mix (Thermo Scientific), $1 \mu \mathrm{l}(10 \mathrm{pmol})$ each of forward and reverse primer and $5 \mu \mathrm{l}$ of template DNA (culture lysate). For sefC and pefA genes, duplex PCR was used. PCR amplification was performed in a Master Cycler Gradient (Bio Rad, USA). The thermal conditions maintained for the amplification of different virulence associated genes are given in Table 2. To monitor the quality control of PCR assays, a reagent blank, which contained all the components except template DNA for which sterile deionised water was substituted and a negative control containing non Salmonella DNA were included in every PCR procedures. The amplified products were analysed by horizontal submarine agarose gel electrophoresis (Sambrook et al., 2001).

\section{Results and Discussion}

All the isolates screened for the detection of virulence-associated genes, were found to be positive for invA and stn genes (100\% positive). None of the isolates were found positive for sefC $(0 \%)$. However, two isolates
(One $S$. typhimurium and one $S$. vircho) from Aizawl, were also found to be positive for pefA and $s p \nu \mathrm{C}$ genes (Table 3, 4; Fig. 1 to 6).

In the present study, we tried to identify the virulence associated genes in the Salmonella isolates from raw pork. $S$. virchow and $S$. typhimurium were the two different Salmonella species identified among the raw pork samples. The presence of invA and stn genes in all the isolates in our study is in agreement with the result obtained by other researchers (Chaudhary et al., (2015); Borges et al., (2013) and Karmi, (2013). However, Ateba and Mochaiwa (2014) investigated for presence of Salmonella isolates from 32 raw beef samples collected from North West Province, South Africa and found 10 out of 96 presumptive isolates were positive for invA gene. In this present study, we also found, $60 \%(3 / 5)$ isolates positive for pepA and $20 \%$ (1/5) positive for $s p v \mathrm{C}$ and $s e f C$ genes. Similar finding was obtained by Das et. al., (2012) who reported presence of $i n v \mathrm{~A}, s t n, p e f \mathrm{~A}, \mathrm{sefC}$ and $s p v \mathrm{C}$ genes in $100 \%, 100 \%, 51.42 \%$, $25.71 \%$ and $42.85 \%$ isolates, respectively. Write here the importance of the detected genes in virulence of Salmonella and if possible the probable reason of absence of some genes in few isolates. Now a day, detection of invA gene by PCR is taken as internationally accepted standard identification tool for Salmonella (Darwin and Miller, 1999) as it is rapid, sensitive and specific for detection of Salmonella from any clinical samples (Lampel et al., 2000).

Fig.1 Distribution of virulence associated genes of Salmonella serovars from Aizawl and Imphal

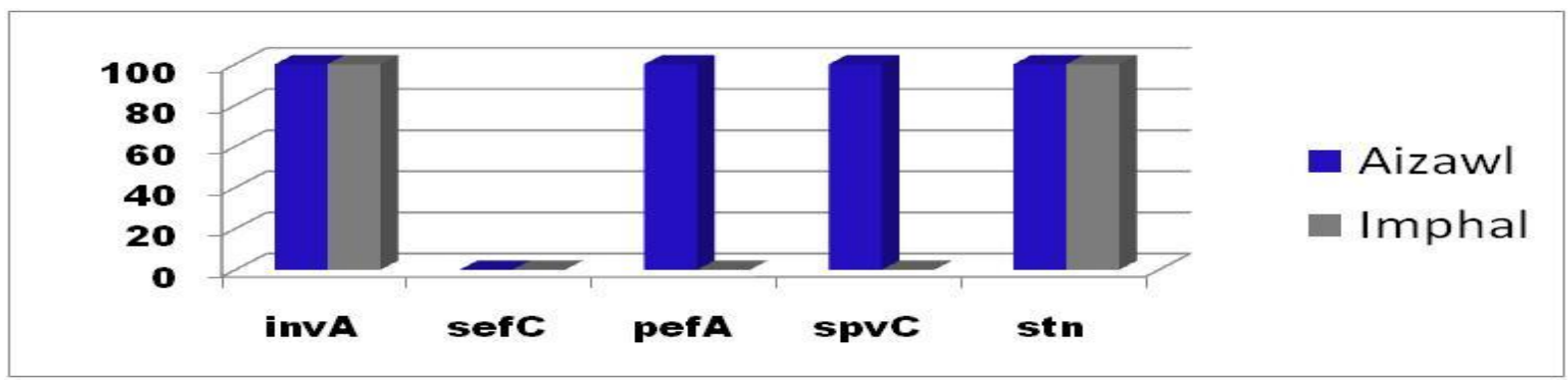


Fig.2 Distribution of virulence associated genes according to Salmonella serovars

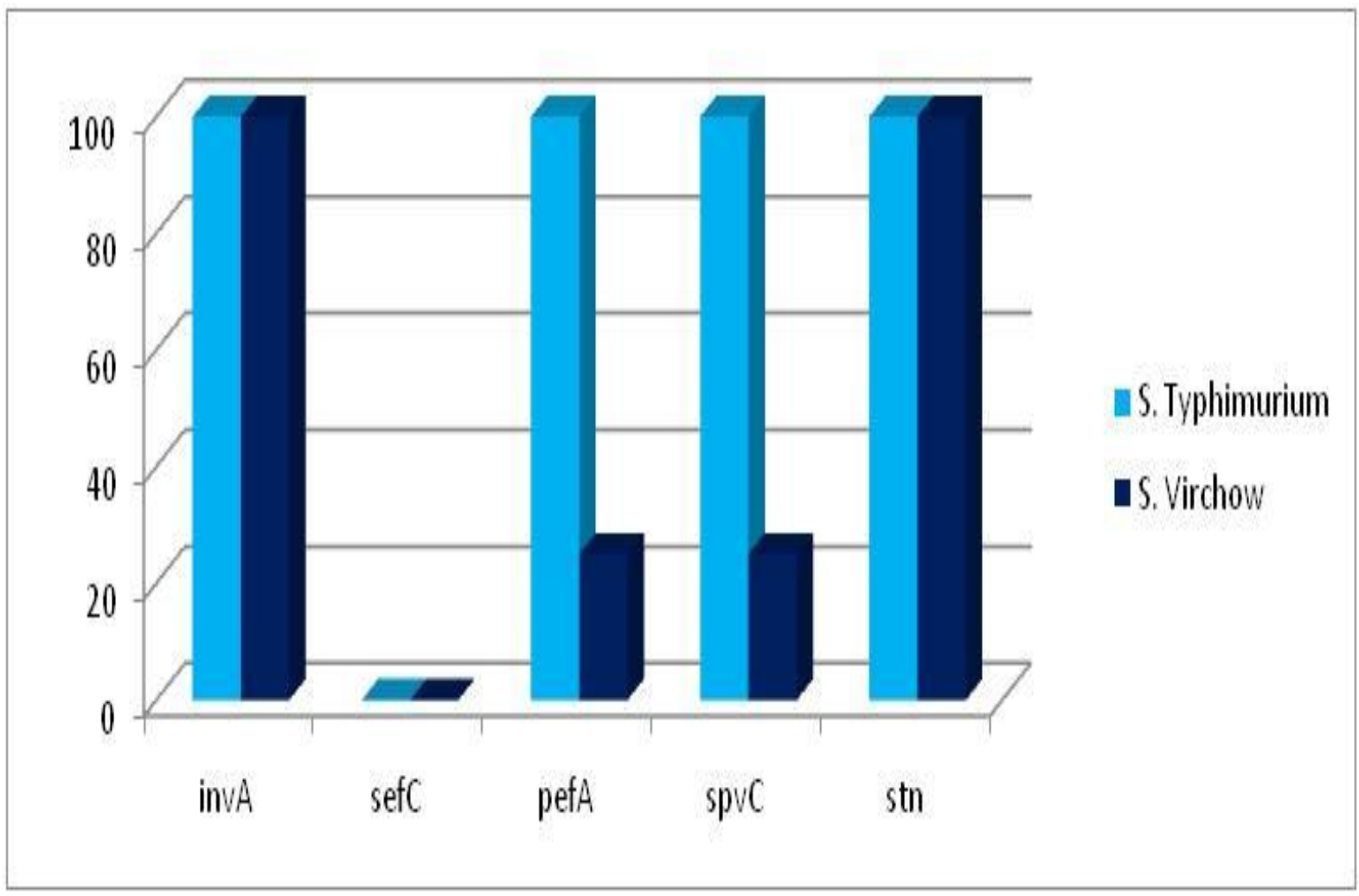

Fig.3 PCR amplification of invA gene (284 bp) in Salmonella isolates

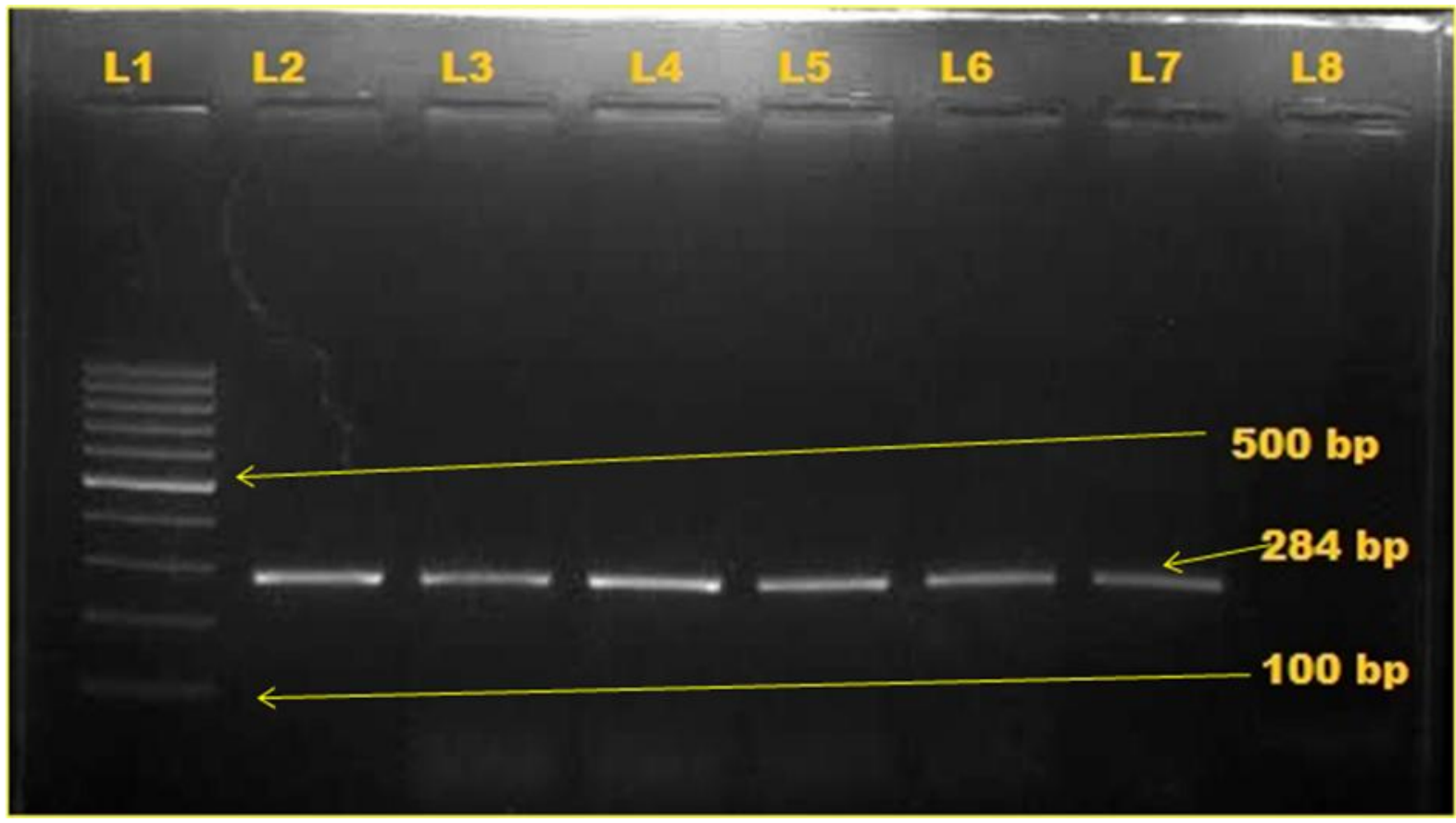

L1 100 bp DNA ladder; L2 Positive control; L3,L4, L5,L6, L7 Samples; L8 Negative control. 
Fig.4 PCR amplification of pefA (700bp) and sefC (1103 bp) gene in Salmonella isolates

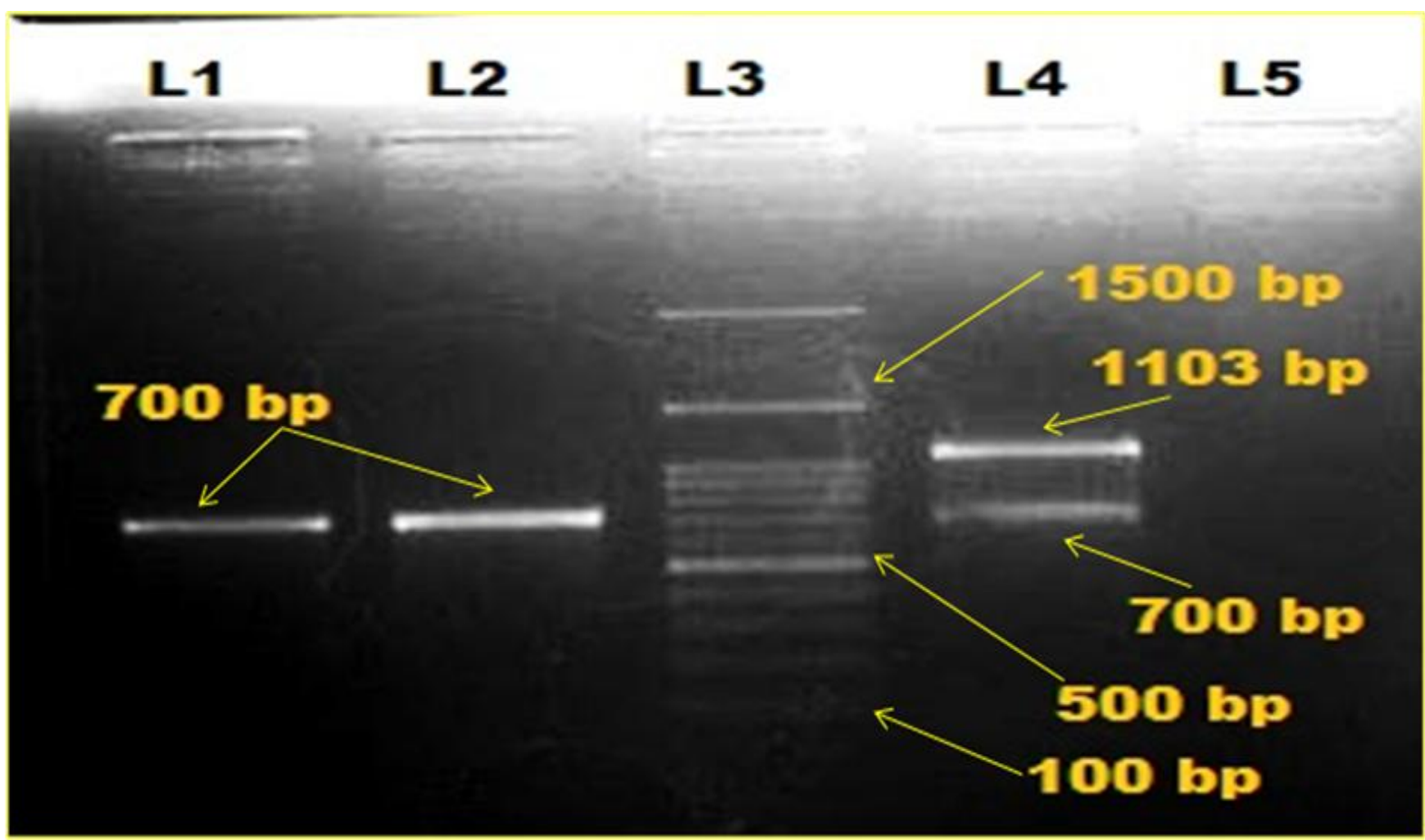

L1, L2 Positive samples; L3 3000 bp DNA ladder; L4 Positive control; L5 Negative control.

Fig.5 PCR amplification of $s p v C(571 \mathrm{bp})$ gene in Salmonella isolates

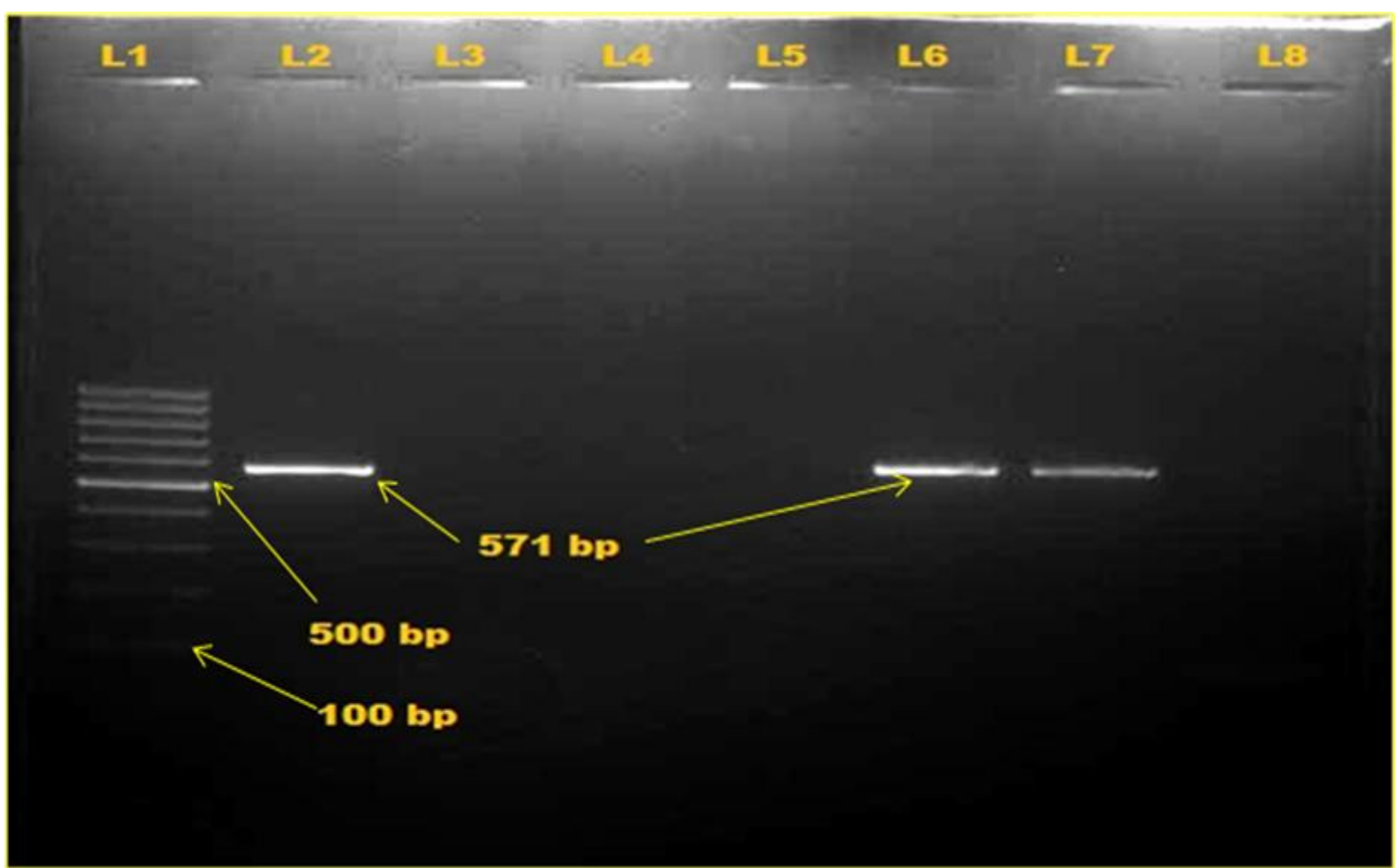

L1 100 bp DNA ladder; L2 Positive control; L3, L4, L5 (negative), L6, L7 (positive) Samples; L8 Negative control. 
Fig.6 PCR amplification of $\operatorname{stn}(617 \mathrm{bp})$ gene in Salmonella isolates

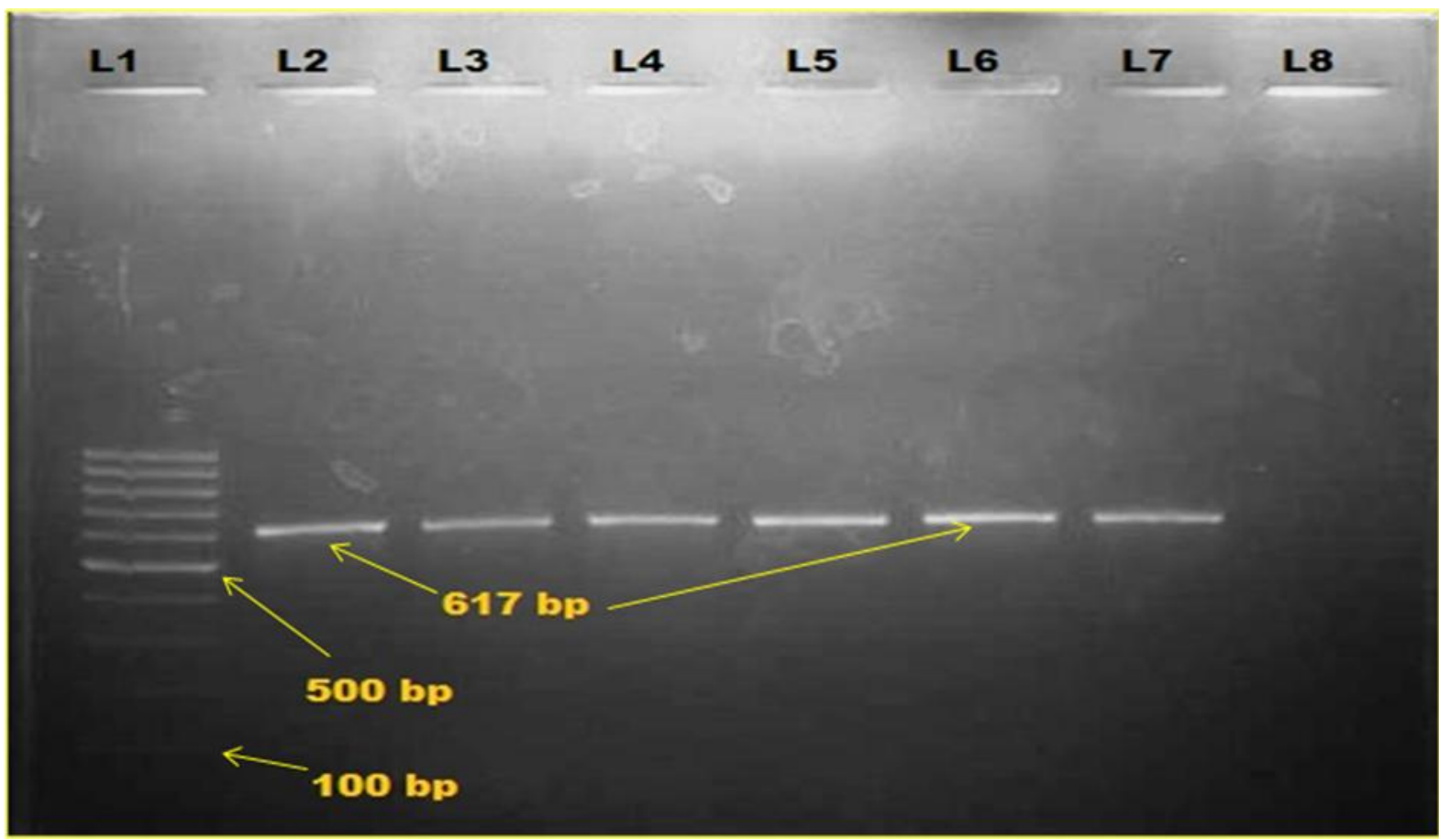

L1 100 bp DNA ladder; L2 Positive control; L3,L4, L5,L6, L7 Samples; L8 Negative control

Table.1 List of oligonucleotide primers used in PCR for detection of virulence-associated genes in Salmonella serovars

\begin{tabular}{|c|c|c|c|c|}
\hline Gene & $\begin{array}{l}\text { Primer } \\
\text { name }\end{array}$ & Primer sequence $\left(5^{\prime} \rightarrow 3^{\prime}\right)$ & $\begin{array}{l}\text { Amplic } \\
\text { on size }\end{array}$ & Reference \\
\hline \multirow[t]{2}{*}{$\operatorname{inv} \mathrm{A}$} & $\operatorname{inv} \mathrm{A} F$ & $\begin{array}{l}\text { GTG AAA TTA TCG CCA CGT TCG GGC } \\
\text { AA }\end{array}$ & \multirow[t]{2}{*}{$284 \mathrm{bp}$} & \multirow{2}{*}{$\begin{array}{l}\text { Rahn et al., } \\
(1992) \text { Kumar } \\
\text { et al., (2008) }\end{array}$} \\
\hline & invA R & TCA TCG CAC CGT CAA AGG AAC C & & \\
\hline \multirow[t]{2}{*}{$\operatorname{sefC}$} & $\operatorname{sefC~} \mathrm{F}$ & GCG AAA ACC AAT GCG ACT GTA & \multirow[t]{2}{*}{$1103 \mathrm{bp}$} & \multirow{2}{*}{$\begin{array}{l}\text { Rahman et } \\
\text { al.,(2000), } \\
\text { Murugkar et al., } \\
(2003)\end{array}$} \\
\hline & sefC R & CCC ACC AGA AAC ATT CAT CCC & & \\
\hline \multirow[t]{2}{*}{ pefA } & pefA F & TGT TTC CGG GCT TGT GCT & \multirow[t]{2}{*}{$700 \mathrm{bp}$} & \multirow{2}{*}{$\begin{array}{l}\text { Clouthier } \\
\text { al.,(1994), } \\
\text { Murugkar } \\
\text { al.,(2003) }\end{array}$} \\
\hline & pefA R & CAG GGC ATT TGC TGA TTC TTC C & & \\
\hline \multirow[t]{2}{*}{$\operatorname{spv} \mathrm{C}$} & $s p v \mathrm{CF}$ & ACT CCT TGC ACAACCAAATGCGGA & \multirow[t]{2}{*}{$571 \mathrm{bp}$} & \multirow{2}{*}{$\begin{array}{l}\text { Chiu et al., } \\
(2006)\end{array}$} \\
\hline & $s p v \mathrm{C} \mathrm{R}$ & TGT CTCTGCATTTCGCCACCATCA & & \\
\hline \multirow[t]{2}{*}{ stn } & $\sin \mathrm{F}$ & TTG TGT CGC TAT CAC TGG CAA CC & \multirow[t]{2}{*}{617 bp } & \multirow{2}{*}{$\begin{array}{l}\text { Prager et } \\
\text { al.,(1995), } \\
\text { Murugkar et al., } \\
(2003)\end{array}$} \\
\hline & $\sin \mathrm{R}$ & ATT CGT AAC CCG CTC TCG TCC & & \\
\hline
\end{tabular}


Table.2 PCR thermal cycling conditions for Salmonella virulence genes (invA, sefC, pefA, spvC and stn)

\begin{tabular}{|c|c|c|c|c|}
\hline Stages & invA & sefC and pefA & $\operatorname{spvC}$ & stn \\
\hline \multicolumn{5}{|l|}{ First cycle } \\
\hline Initial denaturation & $95^{\circ} \mathrm{C}(5 \mathrm{~min})$ & $94^{\circ} \mathrm{C}(4 \mathrm{~min})$ & $94^{\circ} \mathrm{C}(4 \mathrm{~min})$ & $95^{\circ} \mathrm{C}(5 \mathrm{~min})$ \\
\hline \multicolumn{5}{|c|}{ Subsequent 30 cycles(step 2,3 and 4) } \\
\hline Denaturation & $95^{\circ} \mathrm{C}(30 \mathrm{sec})$ & $94^{0} \mathrm{C}(55 \mathrm{sec})$ & $94^{\circ} \mathrm{C}(45 \mathrm{sec})$ & $94^{\circ} \mathrm{C}(1 \mathrm{~min})$ \\
\hline Annealing & $64^{\circ} \mathrm{C}(30 \mathrm{sec})$ & $55^{\circ} \mathrm{C}(55 \mathrm{sec})$ & $56^{\circ} \mathrm{C}(45 \mathrm{sec})$ & $59^{\circ} \mathrm{C}(1 \mathrm{~min})$ \\
\hline Extension & $72^{\circ} \mathrm{C}(45 \mathrm{sec})$ & $72^{0} \mathrm{C}(55 \mathrm{sec})$ & $72^{\circ} \mathrm{C}(1 \mathrm{~min})$ & $72^{\circ} \mathrm{C}(1 \mathrm{~min})$ \\
\hline $\begin{array}{l}\text { Final extension for } \\
1 \text { cycle }\end{array}$ & $72^{0} \mathrm{C}(10 \mathrm{~min})$ & $72^{0} \mathrm{C}(7 \mathrm{~min})$ & $72^{\circ} \mathrm{C}(7 \mathrm{~min})$ & $72^{\circ} \mathrm{C}(10 \mathrm{~min})$ \\
\hline
\end{tabular}

Table.3 Distribution of virulence-associated genes in Salmonella isolates in Aizawl and Imphal

\begin{tabular}{|c|c|c|c|c|}
\hline Genes & Amplicon size & Aizawl (n=2) & Imphal (n=3) & Total \\
\hline invA & $284 \mathrm{bp}$ & $2(100 \%)$ & $3(100 \%)$ & $5(100 \%)$ \\
\hline $\boldsymbol{s e f C}$ & $1103 \mathrm{bp}$ & $0(0 \%)$ & $0(0 \%)$ & $0(0 \%)$ \\
\hline $\boldsymbol{p e f A}$ & $700 \mathrm{bp}$ & $2(100 \%)$ & $0(0 \%)$ & $2(40 \%)$ \\
\hline $\boldsymbol{s p} \boldsymbol{\nu} \mathbf{C}$ & $571 \mathrm{bp}$ & $2(100 \%)$ & $0(0 \%)$ & $2(40 \%)$ \\
\hline $\boldsymbol{s t n}$ & $617 \mathrm{bp}$ & $2(100 \%)$ & $3(100 \%)$ & $5(100 \%)$ \\
\hline
\end{tabular}

Percentage is given in the parentheses

Table.4 Distribution of virulence associated genes in Salmonella isolates according to serovars

\begin{tabular}{|c|c|c|c|c|c|c|}
\hline $\begin{array}{c}\text { Salmonella } \\
\text { Serovars }\end{array}$ & $\begin{array}{c}\text { Total number } \\
\text { of isolates }\end{array}$ & invA & sefC & pefA & spvC & stn \\
\hline $\begin{array}{c}\text { Salmonella } \\
\text { typhimurium }\end{array}$ & 1 & $1(100 \%)$ & 0 & $1(100 \%)$ & $1(100 \%)$ & $1(100 \%)$ \\
\hline $\begin{array}{c}\text { Salmonella } \\
\text { Vircho }\end{array}$ & 4 & $4(100 \%)$ & & $1(25 \%)$ & $1(25 \%)$ & $4(100 \%)$ \\
\hline
\end{tabular}

Percentage is given in the parentheses

It is concluded that, detection of virulence associated genes from Salmonella isolates concludes that Salmonella is highly pathogenic organism and $100 \%$ positivity of invA and stn gene supports the fact that, these two genes are present irrespective of serovars and can act as the rapid identification tool for Salmonella in future. Presence of Salmonella typhimurium with maximum virulence associated gene is an alarming situation for
Aizawl in public health and hygienic point of view. Albeit, more number of samples need to be studied to confirm the pattern of presence of virulence related genes of Salmonella from the isolates from raw pork available at Aizawl and Imphal cities as well as other major cities in North-eastern India, it is quite pertinent to take appropriate measures to improve the hygiene of local pork markets to minimize the health hazards to the consumers. 


\section{Acknowledgement}

Authors are grateful to Prof. T. K. Dutta, Department of Veterinary Microbiology, CVSc\& AH, CAU, Selesih, Aizawl, Mizoram, for providing the standard culture of Salmonella enteritidis (ATCC 13076) (positive for invA, $s e f \mathrm{C}$, pef $\mathrm{A}, s p v \mathrm{C}$ and stn gene) and respected Dean and Research Council of the college, CVSC \& AH, CAU for extending full support during the study.

\section{References}

Alcaine, S.D., Warnick, L.D. and Wiedmann, M. 2007. Antimicrobial resistance in nontyphoidal Salmonella. J. Food Prot. 70: 780-790.

Ateba, C.N. and Mochaiwa, B. 2014. Use of invA Gene Specific PCR Analysis for the Detection of Virulent Salmonella Species in Beef Products in North West Province, South Africa. J. Food Nutri. Res. 2(6): 294-300.

Baumler, A.J., Tsolis, R.M., Bowe, F.A., Kuster, J.G. and Hoffmanns, H.F. 1996. The pef fimbrial operon of Salmonella typhimurium medicates adhesion to murine small intestine and is necessary for fluid accumulation in the infant mouse. Infect. Immun. 64: 61-68.

Blanc-Potard, A.B. and Groisman, E.A. 1997. The Salmonella selC locus contains a pathogenecity island meditating intramacrophage survival. EMBO. 16: 5376-5385.

Borges, K. A., Furian, T.Q., Anderlise, B., Hamilto, L.S., Carlos, T.P. and Vladimir, P.N. 2013. Detection of virulenceassociated genes in Salmonella enteritidis isolates from chicken in South of Brazil. Pesq. Vet. Bras. 33(12):1416-1422.

Bradeeba, K. and Sivakumaar, P.K. 2013. Assessment of microbial quality of beef, mutton and pork and its environment in retail shops in Chidambaram, Tamil Nadu. Int. J. Plant Anim. Environ. 3(1): 91-97.

Chaudhary, J.H., Nayak, J.B., Brahmbhatt,
M.N. and Makwana, P.P. 2015. Virulence genes detection of Salmonella serovars isolated from pork and slaughterhouse environment in Ahmedabad, Gujarat. Vet. World. 8(1): 121-124.

Chiu, C., Su, L., Chu, C., Wang, M., Yeh, C., Weill, F.X. and Chu, C. 2006. Detection of Multidrug-Resistant Salmonella enteric Serovar typhimurium Phage Types DT102, DT104 and U302 by Multiplex PCR. J. Clin. Microbiol. 44(7): 23542358.

Chopra, A.K., Peterson, J.W., Chary, P. and Prasad, R. 1994. Molecular characterization of an enterotoxin from Salmonella typhimurium. Microbial Pathogen. 16(2): 85-98.

Clothier, S.C., Muller, K.H., Doran, J.L., Collinson, S.K. and Kay, W.W. 1993. Characterization of three fimbrial genes, sefABC of Salmonella enteritidis. J. Bacteriol. 175: 2523-2533.

Clouthier, S.C., Collinson, S.K., Kay, W.W. (1994). Unique fimbriae-like structures encoded by sefD of the SEF 14 fimbrial gene cluster of Salmonella enteritidis. Mol. Microbiol. 12: 893-901.

Darwin, K. H. and V. L. Miller. 1999. Molecular basis of the interaction of Salmonella with the intestinal mucosa. Clin. Microbiol. Rev. 12: 405-428.

Das, A., Hari, S.S., Shalini, U., Ganeshkumar, A. and Karthikeyan, M. 2012. Molecular screening of Virulence Genes from Salmonella enterica isolated from Commercial Food Stuffs. Biosci. Biotech. Res. Asia. 9(1): 363-369.

Das, M., E. Motina, D. Deka, N.S. Singh, T.K. Dutta, P. Roychoudhury and S. Chakraborty. 2018. Bacteriological quality of raw pork sold in retailed butcher shops of Aizawl and Imphal. Int. J. Curr. Microbiol. Appl. Sci. 7(05): 1189-1195.

Dhanze, H., Khurana, S.K. and Mane, B.G. 2012.Microbiological quality of eggs, chicken and chevon sold in market of Palampur, H.P. J. Vet. Pub.Hlth. 10(1): 53-55. 
Fernandez, A.E., Calleja, A.C., Fernandez, G.C. and Capita, R. 2012. Prevalence and antimicrobial resistant of Salmonella serotypes isolated from poultry in Spain: comparison between 1993 and 2006. Int. J. Food Microbiol. 153: 281-287.

Galan, J.E. and Curtiss, R. 1989. Cloning and molecular characterization of genes whose products allow $S$. typhimurium to penetrate tissue culture cells. Proc. Natl. Acad. Sci. 86: 6383-6387.

Galan, J.E., Ginocchio, C. and Costeas, P. 1992. Molecular and functional characterization of the Salmonella invasion gene invA: homology of invA to members of a new protein family. J. Bacteriol. 174: 43384349.

Karmi, M. 2013. Detection of Virulence Gene (inva) in Salmonella isolated from Meat and poultry products. Int. J. Gen. 3(2): 712

Kumar, K., Saklaini, A.C., Singh, S. and Singh, V.P. 2008. Evaluation of specificity for invA gene PCR for detection of Salmonella spp. Proceeding of VIIth Annual Conference of Indian Association of Veterinary Public Health Specialists (IAVPHS). November 07- 09-2008.

Lampel, K. A., Orlandi, P. A. and Kornegay, L. 2000. Improved template preparation for PCR-based assay for detection of foodborne bacterial pathogens. Appl. Environ. Microbiol. 66: 4539-4542.

Movassagh, M.H., Shakoori, M. and Zolfaghari, J. 2010. The prevalence of Salmonella spp. in Bovine carcass at Tabriz slaughterhouse, Iran. Global Vet. 5920: 146-149.

Murugkar, H.V., Rahman, H. and Dutta, P.K. 2003. Distribution of virulence genes in
Salmonella serovars isolated from man and animals. Ind. J. Med. Res. 117: 6670.

Pignato, S., Giammanco, G., Santangelo, C. and Giammanco, G. 1998. Endemic presence of Salmonellabongori48:Z35: Causing enteritis in children in Sicily. Res. Microbiol. 149: 429-431

Prager, R., Fruth, A., Tschape, H. 1995. Salmonella enterotoxin (stn) gene is prevalent among strains of Salmonella enteric but not among Salmonella bongori and other Enterobacteriaceae. FEMS Immunol. Med. Microbiol. 12: 47-50.

Prakash, B., Krishnappa, G., Muniyappa, L. and Santhosh, K.B. 2005. Epidemiological characterization of avian Salmonella enteric serovar infections in India. Int. J. Poult. Sc. 4:388-395.

Rahman, H., Prager, R., Tschape. H. 2000. Occurrence of sef and pef genes among different serovars of Salmonella. Ind. J. Med. Res. 111: 40-2.

Rahn, K., De Grandis, S.A., Clarke, R.C., McEwen, S.A., Galan, J.E., Ginocchio, C., Curtiss, R3rd. and Gyles, C.L. 1992. Amplification of an invA gene sequence of Salmonella typhimurium by polymerase chain reaction as a specific method of detection of Salmonella. Mol. Cell Probes. 6: 271-279.

Sambrook, J. and Russel, D.W. 2001. Plasmid and their usefulness in molecular cloning. Molecular cloning A Laboratory Manual. Third edition. Cold Spring Harbour Laboratory press. New York. Pp. 1-32.

Wallis, T.S. and Galyor, E.E. 2000. Molecular basis of Salmonella induced enteritis. Mol. Microbiol. 36: 997-1005.

\section{How to cite this article:}

Das, M., E. Motina, D. Deka, T.K. Dutta, P. Roychowdhury, A. De and Chakraborty, S. 2019. Molecular Detection of Virulence Associated Genes in Salmonella Serovars Isolated From Raw Pork of Aizawl and Imphal. Int.J.Curr.Microbiol.App.Sci. 8(07): 23-31. doi: https://doi.org/10.20546/ijcmas.2019.807.004 